\title{
GENETIC CONNECTIVITY OF MULLETS (Mugil liza) BETWEEN RODRIGO DE FREITAS LAGOON AND A CONSERVATION UNIT IN STATE OF RIO DE JANEIRO, SOUTHEASTERN BRAZIL
}

\author{
Anderson Vilasboa de Vasconcellos ${ }^{1 *}$, Livia Bonetti Villela ${ }^{1,3}$, Denise Borges dos Santos Dias ${ }^{l}$, \\ Karina Alessandra Morelli ${ }^{1}$, Carolina Tavares Schumann ${ }^{1,2}$ \& Jaqueline Gusmão ${ }^{l}$
}

\footnotetext{
${ }^{1}$ Universidade do Estado do Rio de Janeiro, Departmento de Genética, Laboratório de Genética Pesqueira e da Conservação, Rua São Francisco Xavier, nº 524, CEP 20500-900, Rio de Janeiro, RJ, Brazil.

${ }^{2}$ Instituto de Aplicação Fernando Rodrigues da Silveira, Departmento de Ciências Naturais, Rua Santa Alexandrina, $n^{\circ}$ 288, CEP 20261-232, Rio de Janeiro, RJ, Brazil.

${ }^{3}$ Universidade Federal do Rio de Janeiro, Instituto de Biologia, Labaratório de Fitoplancton Marinho, Rua Prof. Rodolpho P. Rocco, n 211, CEP 21941-617, Rio de Janeiro, RJ, Brazil.

Emails: anderson.vasconcellos@uerj.br (*corresponding author); liviabvillela@gmail.com,ddias2006@gmail.com; karinamorelli@gmail.com; cr_tavares@hotmail.com; gusmao.jaque@gmail.com
}

\begin{abstract}
We analyzed the genetic connectivity between mullets (Mugil liza) captured around the protected Natural Monument of Cagarras Islands (MoNa Cagarras) and inside Rodrigo de Freitas Lagoon, using microsatellite markers polymorphisms. Our data revealed the occurrence of 31 shared alleles (from 41 sampled), a high similarity in both allelic frequencies and genetic diversity and lack of differentiation between collection points ( $\mathrm{F}_{\mathrm{ST}}=0.000, \mathrm{p}>0.05$, STRUCTURE best estimative $\left.\mathrm{K}=1\right)$, results which, analyzed together, are strongly indicative of panmixia. We conclude that individuals collected inside the Rodrigo de Freitas Lagoon are genetically similar to those individuals collected around MoNa Cagarras. Given the importance of estuaries for the reproduction and development of individuals of $M$. liza, it is recommended that the Rodrigo de Freitas Lagoon to be managed in order to maintain genetic connectivity and diversity between the two ecosystems.
\end{abstract}

Keywords: coastal ecosystem; gene flow; microsatellite

The mullet Mugil liza (Mugiliformes: Mugilidae) is a widely distributed pelagic species of the Atlantic Coast in South America, occurring from Venezuela to Argentina (Menezes et al. 2010, Siccha-Ramirez et al. 2014). The species is mainly related to sheltered and coastal waters with a predominant (but not mandatory) migratory behavior to the open sea at the spawning time (Vieira 1991, Fortunato et al. 2017). Most of the individuals enter estuarine waters and uses it as a nursery, remaining in this habitat until the recruitment for adult population (Vieira et al. 2008, Potter et al. 2013, Garbin et al. 2014), but some individuals may spend part or whole life exclusively in estuaries or in open sea (Fortunato et al. 2017). This is a very important fisheries resource for local fishermen in the municipality of Rio de Janeiro since it is one of the most abundant fisheries inside Rodrigo de Freitas Lagoon (Andreata et al. 2002).

Genetic markers have been used as an effective tool to improve the understanding of important 
aspects of population dynamics and structure, as well as the evolutionary processes and genetic drift of fish species (Cuéllar-Pinzón et al. 2016). Through the analysis of genetic variation, it is possible to analyze migration events, the contribution of each population to the formation of genetic stocks and connectivity between metapopulations (Kasapadis et al. 2012). In Brazil, previous genetic analysis indicates the existence of two distinct populations of M. liza along the coast: 1) One population restricted to the state of Rio de Janeiro; and 2) another population distributed (at least) from the State of São Paulo (Brazil) through Argentina (Mai et al. 2014).

The "Monumento Natural do Arquipélago das Ilhas Cagarras - MoNa Cagarras" (Natural Monument of Cagarras Island Archipelago) is a fully protected conservation unit (UC) that consists of four islands (Cagarras, Palmas, Comprida and Redonda) and the islets Filhote da Cagarras and Filhote da Redonda (Figure 1). The purpose of the UC is to preserve the remnants of the Atlantic Forest domain ecosystem, the refuges and nesting areas of migratory seabirds, and the local scenic beauty (Brasil 2020). Around the islands water depths reach $20 \mathrm{~m}$ and are abundant in fish and a closed area for fishing (Bertoncini et al. 2013). This closed area is recognized as important in maintaining fisheries abundance near this area (Amorim \& MonteiroNeto 2016).

The Rodrigo de Freitas Lagoon (RFL) is an important ecosystem of Rio de Janeiro (Figure 1) to reproduction, nutrition, and growth of several fish species. It is also used for commercial fishing, tourism, leisure, and water sports activities (Gonzalez et al. 2006). Rodrigo de Freitas Lagoon had its origin in the drowning of old fluvial basins generated by transgressive-regressive variations of sea level that occurred in the past 6,000 years (Amador 1997). Currently, the artificial channel called "Jardim de Alah" that was constructed in the 1920s makes the connection between RFL and the open sea. However, for a long time, the lagoon was an enclosed area with sporadic sea connections only at times of rising tide. This long-term isolation between RFL and the Ocean may have led to the emergence of two genetically

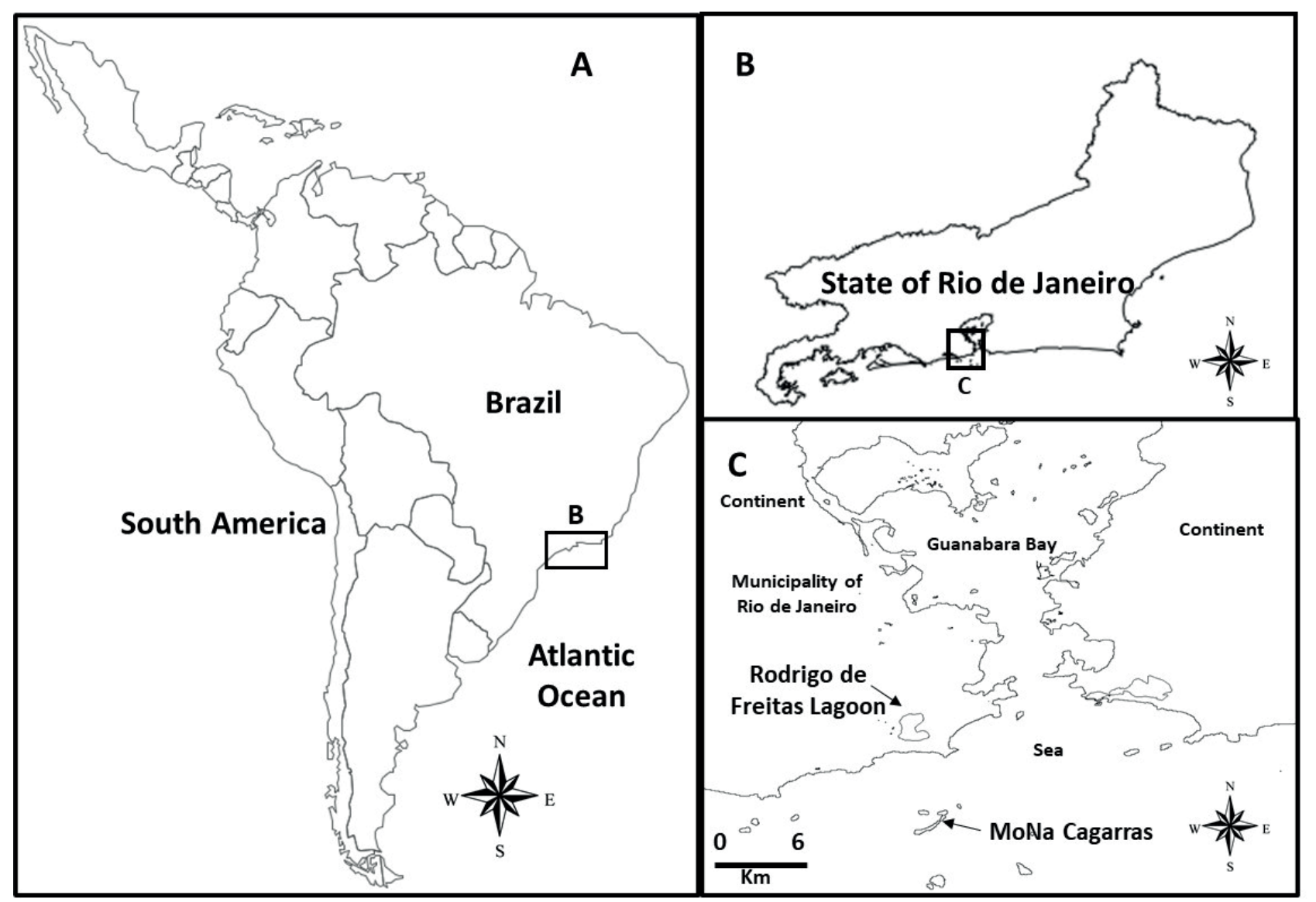

Figure 1. Map of South America (A), Rio de Janeiro State (B) and municipality of Rio de Janeiro (C) showing sampling locations of M. liza. 
distinct mullet populations. Another possible scenario could be that frequent fluctuations in mortality rate, due to pollution in the lagoon, would lead to a rapid differentiation between two areas. Based on these premises, this study aimed to evaluate the genetic connectivity degree between mullets collected inside LRF and in the near areas of MoNa Cagarras.

Muscle tissue samples were obtained from fish captured between August and September 2018 in RFL ( $\mathrm{N}=28)$ and in areas near MoNa Cagarras ( $\mathrm{N}$ $=34$ ). These samples were stored in $70 \%$ ethanol or frozen immediately after collection for further processing. DNA extraction was performed according to the saline extraction protocol (modified from Miller et al. 1988). The extracts were quantified in nanodrop and high-quality DNA was stored at $-20{ }^{\circ} \mathrm{C}$. Polymerase Chain Reaction (PCR) assays were performed using heterologous primers developed for a congeneric species. Seven heterologous microsatellite primers (Miggiano et al. 2005, Shen et al. 2010) were selected and used in PCR amplification. In order to genotype the microsatellites, we employed the method described in Schuelke (2000). PCR reactions were performed using $1 U$ Taq DNA polymerase (Sinapse), $0.2 \mathrm{mM}$ of each dNTPs, $0.5 \mu$ M of each primer, $2 \mathrm{mM} \mathrm{MgCl}_{2}, 1 \mathrm{XPCR}$ buffer and $1 \mu \mathrm{L}$ DNA (30 $\mathrm{ng} / \mu \mathrm{L})$, in a final volume of $15 \mu \mathrm{L}$. Amplification conditions were: an initial cycle at $94{ }^{\circ} \mathrm{C}$ for 5 minutes (min), followed by 43 cycles (35 amplification cycles followed by 8 cycles for incorporation of fluorescence) from 1 min at $94{ }^{\circ} \mathrm{C}, 1 \mathrm{~min}$ at $53^{\circ} \mathrm{C}$ and $1 \mathrm{~min}$ at $72^{\circ} \mathrm{C}$. An additional extension cycle was $72{ }^{\circ} \mathrm{C}$ for $30 \mathrm{~min}$. Amplified products were detected by $1 \%(\mathrm{v} / \mathrm{v})$ agarose gel electrophoresis in 0.5X TBE buffer, stained with ethidium bromide and visualized under UV light. Genotyping was performed on a 3130xl automatic sequencer with GeneScan 500 (Life technologies) as size marker.

The resulting electropherograms were analyzed using the GeneMarker software (SoftGenetics LLC - free trial version) in which the genotypes were manually determined. Descriptive statistics (i.e., gene frequencies, number of alleles, accordance with Hardy-Weinberg Equilibrium, and linkage disequilibrium) were calculated in FSTAT 2.9.3 (Goudet 2001). To assess the occurrence of problems inherent to genotyping was used the Micro-Checker (Van Oosterhout et al. 2004). The pairwise $\mathrm{F}_{\mathrm{ST}}$ fixation index calculation was performed using Arlequin 3.5 program (Excoffier \& Lischer 2010). A correspondence factorial analysis (AFC) was made to visualize the distribution of genetic variation among individuals in a multidimensional space in the Genetix 4.05 (Belkhir et al. 2002). The genetic structure was also analyzed with a Bayesian analysis as implemented in the STRUCTURE (Pritchard et al. 2000). Analyses were performed with one million Monte Carlo Markov Chain (MCMC) steps, discarding the first $20 \%$ of iterations as burn-in. Each analysis was repeated 5 times for each simulated value of $\mathrm{K}$, which ranged from 1 to 2 groups. Structure Harvester was used to infer the most likely number of clusters (K) (Earl \& Von Holdt 2012).

Among the seven markers used, three were monomorphic and were excluded from further analysis. None of the sampled loci showed any evidence of amplification artifacts, HardyWeinberg Equilibrium deviations, or linkage disequilibrium between loci. The analyzed data revealed the occurrence of 41 alleles of which 31 are shared among individuals sampled from both locations. A high similarity in allelic frequencies (Figure 2) and genetic diversity (Table 1) was observed among the samples.

The $\mathrm{F}_{\mathrm{ST}}$ structuring index showed genetic differences between individuals from the two locations $\left(\mathrm{F}_{\mathrm{ST}}=0.000, \mathrm{p}>0.05\right)$. High genetic similarity revealed by Bayesian partition $(K=1)$ (Figure 3) and AFC (Figure 4), is indicative of a consistent panmixia scenario.

The genetic data allow the conclusion that the individuals collected inside the Rodrigo de Freitas Lagoon are genetically very similar to those individuals collected around $\mathrm{MoNa}$ Cagarras. Thus, we may conclude that mullets can migrate between MoNa Cagarras and Rodrigo de Freitas Lagoon and, given the importance of estuaries for the reproduction and development of individuals of the species, it is recommended that the Lagoon be managed in order to maintain genetic connectivity and diversity between the two ecosystems, what could be relevant in maintaining the region's fishing stock and in the conservation of the species. 


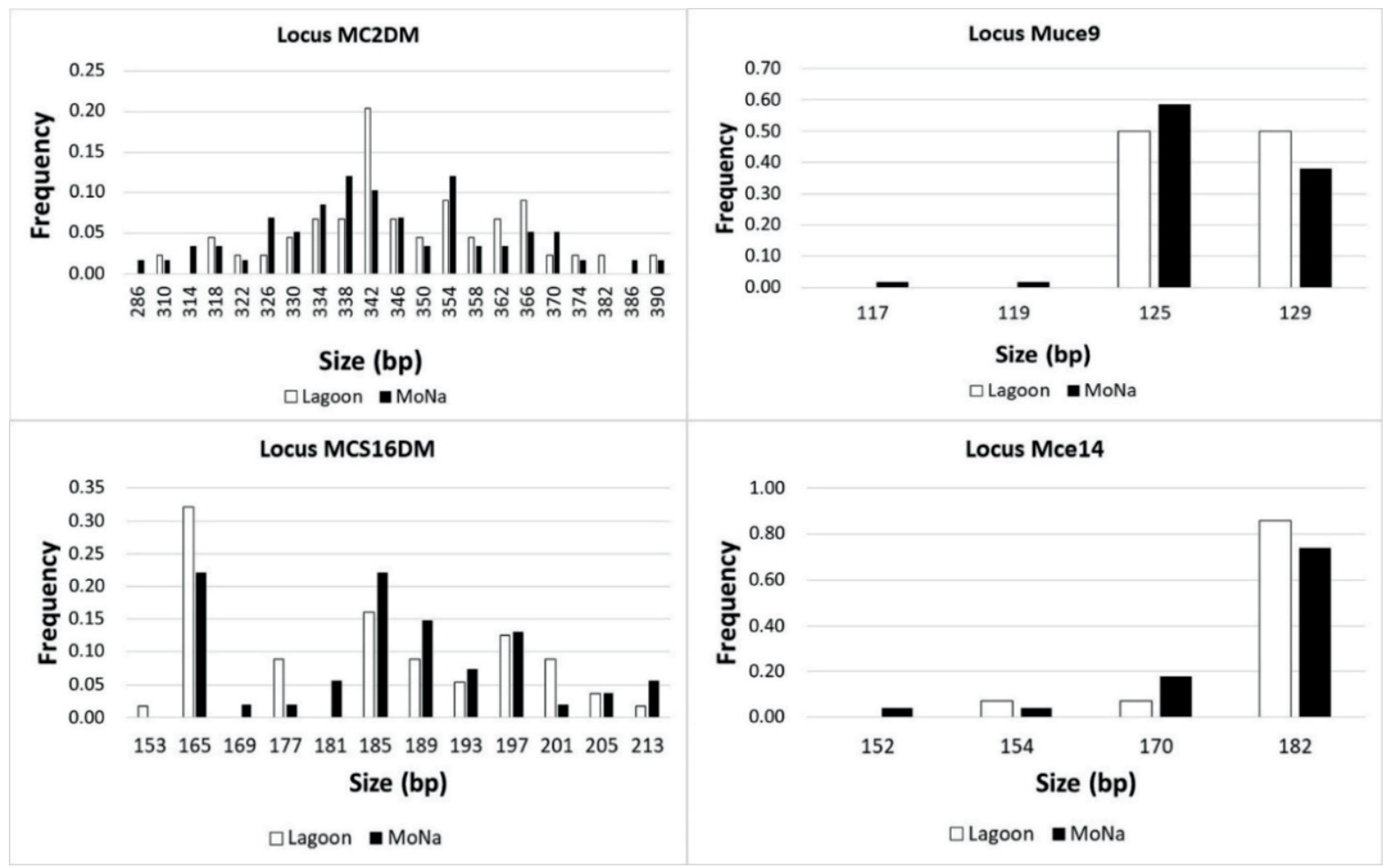

Figure 2. Allele frequencies from four sampled microsatellite loci. White bars represent allele frequencies in individuals from the Rodrigo de Freitas Lagoon and Black bars represent allele frequencies in individuals from the MoNa Cagarras. Alleles are labelled according to their size in number of base pairs (bp).

Table 1. Genetic diversity per locus and sampling location. $\mathrm{N}_{\mathrm{A}}$ : Number of alleles. Number of analyzed individuals: Rodrigo de Freitas Lagoon ( $\mathrm{N}=28)$; MoNa Cagarras $(\mathrm{N}=34)$.

\begin{tabular}{lcccc}
\hline \multirow{2}{*}{ Locus } & \multicolumn{2}{c}{ Rodrigo de Freitas Lagoon } & \multicolumn{2}{c}{ MoNa Cagarras } \\
\cline { 2 - 5 } & Gene diversity & $\mathbf{N}_{\mathbf{A}}$ & Gene diversity & $\mathbf{N}_{\mathbf{A}}$ \\
\hline MC2DM & 0.937 & 18 & 0.946 & 20 \\
Muce9 & 0.505 & 2 & 0.524 & 4 \\
Mcs16d & 0.843 & 10 & 0.867 & 11 \\
Mce14 & 0.369 & 3 & 0.428 & 4 \\
\hline
\end{tabular}



Figure 3. Log-likelihood values of $\mathrm{K}$ from $\mathrm{K}=1$ to $\mathrm{K}=2$ obtained from Bayesian Clustering analysis implemented in STRUCTURE. 


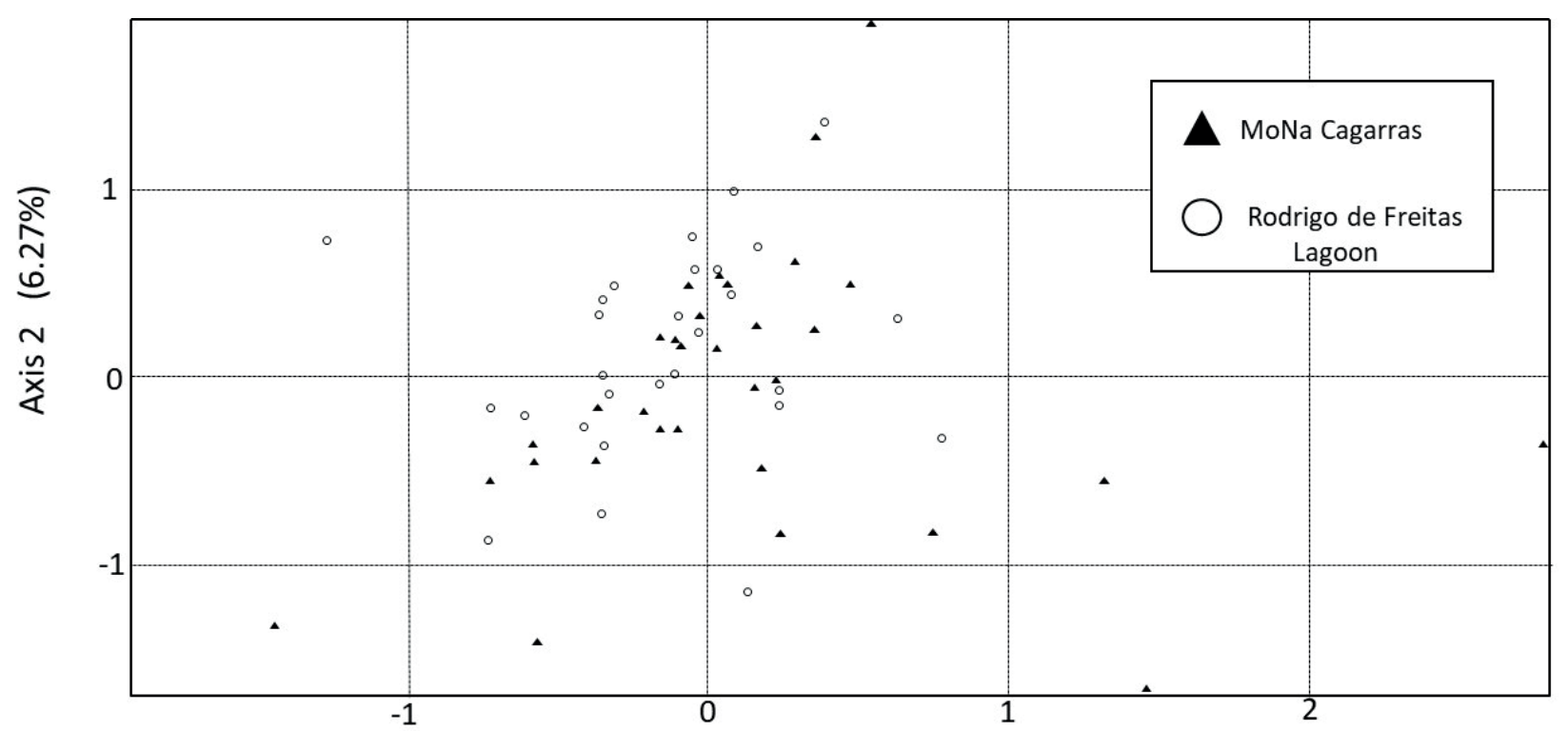

Axis 1 (7.32\%)

Figure 4. Scatter plot from Factorial Analysis of Correspondence of each individual. Individuals from Rodrigo de Freitas Lagoon are presented as white circles and individuals from MoNa Cagarras are presented as black triangles.

\section{ACKNOWLEDMENTS}

The results of this study are part of "Projeto Ilhas do Rio", sponsored by Petrobras (Brazilian Petroleum Company) through the program Petrobras Ambiental. We gratefully thank Gabriel Araújo, Yan Kurtz and Ingrid Garantizado for help in DNA extraction and the Program for Technological Development Tools for Health-PDTIS-FIOCRUZ for use of its facilities. We want to thank Elisa Gusmão for reviewing the manuscript. We are in debt with the fisherman Mr. Orlando for providing samples for pilot experiments.

\section{REFERENCES}

Amador, E. S. 1997. Baía de Guanabara e ecossistemas periféricos - Homem e Natureza. Rio de Janeiro: Reproarte Gráfica e Editora: p. 529.

Amorim, R. B. \& Monteiro Neto, C. 2016. Marine protected area and the spatial distribution of the gill net fishery in Copacabana, Rio de Janeiro, RJ, Brazil. Brazilian Journal of Biology, 76 (1), 1-9. DOI: 10.1590/1519-6984.06614

Andreata, J. V., Manzano, F. V., Baptista, M. G. S., Teixeira, D. E., Oliveira, L. O. V., Longo, M. M., Freret, N. V. \& Valois, A. S. 2002. Assembléia de peixes da lagoa Rodrigo de Freitas, Rio de Janeiro. Bioikos, 16 (1): 19-28.
Belkhir, K., Borsa, P., Chikhi, L., Raufaste, N. \& Bonhomme, F. 2002. GENETIX 4.04, logiciel sous Windows TM pour la génétique des populations. Laboratoire Génome, Populations, Interactions, CNRS UMR 5000, Université de Montpellier II, Montpellier (France).

Bertoncini, A. A., Rangel, C. A., Chaves, L. C. T., Mendonça-Neto, J. P. \& Monteiro Neto, C. 2013. Peixes Recifais do Monumento Natural das Ilhas Cagarras. In: Moraes, F., Bertoncini, A. \& Aguiar, A. (Eds.), História, Pesquisa e Biodiversidade do Monumento Natural das Ilhas Cagarras. pp. 107-137. Rio de Janeiro: Museu Nacional.

Brasil, 2020. Plano de manejo do monumento natural do arquipélago das Ilhas Cagarras. Instituto Chico Mendes de Conservação da Biodiversidade (ICMBio). Brasília, DF.

Cuéllar-Pinzón, J., Presa, P., Hawkins, S. \& Pita, A. 2016. Genetic markers in marine fisheries: Types, tasks and trends. Fisheries Research, 173, 194-205. DOI:10.1016/j.fishres.2015.10.019

Earl, D. \& Von Holdt, B. 2012. STRUCTURE HARVESTER: a website and program for visualizing STRUCTURE output and implementing the Evanno method. Conservation Genetics Resources, 4, 359-361. DOI: 10.1007/s12686-011-9548-7

Excoffier, L. \& Lischer, H. E. L. 2010. Arlequin suite ver 3.5: A new series of programs to perform 
population genetics analyses under Linux and Windows. Molecular Ecology Resources, 10, 564-567. DOI: 10.1111/j.1755-0998.2010.02847.x

Fortunato, R. C., González-Castro, M., Galán, A. R., Alonso, I. G., Kunert, C., Durà, V. B. \& Volpedo, A. 2017. Identification of potential fish stocks and lifetime movement patterns of Mugil liza Valenciennes 1836 in the Southwestern Atlantic Ocean. Fisheries Research, 193, 164-172. DOI: 10.1016/j.fishres.2017.04.005

Garbin, T., Castello, J. P. \& Kinas, P. G. 2014. Age, growth and mortality of the mullet Mugil liza in Brazil's southern and southeastern coastal regions. Fisheries Research, 49, 61-68. DOI: 10.1016/j.fishres.2013.09.008

Gonzalez, A. M., Paranhos, R. \& Lutterbach, M. S. 2006. Heterotrophic bacteria abundances in Rodrigo de Freitas Lagoon (Rio de Janeiro, Brazil). Brazilian Journal of Microbiology, 37 (4), 428-433. DOI: 10.1590/ S1517-83822006000400005

Goudet, J. 2001. FSTAT, a program to estimate and test gene diversities and fixation indices (version 2.9.3). Avaiable at: http://www2.unil. ch/popgen/softwares/fstat.htm.

Kasapidis, P., Silva, A., Zampicinini, G. \& Magoulas, A. 2012. Evidence for microsatellite hitchhiking selection in European sardine (Sardina pilchardus) and implications in inferring stock structure. Scientia Marina, 76, 123-132. DOI: 10.3989/scimar.03366.29B

Mai, A. C. G., Miño, C. I., Marins, L. F., MonteiroNeto, C., Miranda, L., Schwingel, P. R., Lemos, V. N., Gonzalez-Castro, M., Castello, J. P \& Vieira, J. P. 2014. Microsatellite variation and genetic structuring in Mugil liza (Teleostei: Mugilidae) populations from Argentina and Brazil. Estuarine, Coastal and Shelf Science, 149, 80-86. DOI: 10.1016/j.ecss.2014.07.013.

Menezes, N. A., Oliveira, C. \& Nirchio, M. 2010. An old taxonomic dilemma: the identity of the western south Atlantic Lebranche Mullet (Teleostei: Perciformes: Mugilidae). Zootaxa, 2519, 59-68. DOI: 10.5281/zenodo.196200

Miggiano, E., Lyons, R. E., Li, Y., Dierens, L. M., Crosetti, D. \& Sola, L., 2005. Isolation and characterization of microsatellite loci in the striped mullet, Mugil cephalus. Molecular Ecology Resources, Primer Notes, 5, 323-326. DOI:10.1111/j.1471-8286.2005.00915.x
Miller, S. A., Dykes, D. D. \& Polesky, H. F. 1988. A simple salting out procedure for extracting DNA from human nucleated cells. Nucleic Acids Research, 16, 1215. DOI: 10.1093/nar/16.3.1215

Potter, I. C., Tweedley, J. R., Elliott, M. \& Whitfield, A. K. 2013. The ways in which fish use estuaries: a refinement and expansion of the guild approach. Fish and Fisheries, 16 (2), 230-239. DOI: 10.1111/faf.12050

Pritchard, J. K., Stephens, M. \& Donnelly, P. 2000. Inference of population structure using multilocus genotype data. Genetics, 155, 945959.

Schuelke, M. 2000. An economic method for the fluorescent labeling of PCR fragments. Nature Biotechnology, 18, 233-234. DOI: 10.1038/72708 Shen, K. N., Chen, C. Y., Tzeng, W. N., Chen, J. D., Knibb, W. \& Durand, J. D. 2010. Development and characterization of 13 GT/CA microsatellite loci in cosmopolitan flathead mullet Mugil cephalus. Molecular Ecology Resources, 10 (6), 1098-1105. DOI: 10.1007/s12686-011-9400-0

Siccha-Ramirez, R., Menezes, N. A., Nirchio, M., Foresti, F. \& Oliveira, C. 2014. Molecular identification of mullet species of the Atlantic South Caribbean and South America and the phylogeographic analysis of Mugil liza. Reviews in Fisheries Science and Aquaculture, 22 (1), 86-96. DOI: 10.1080/10641262.2013.833583

Van Oosterhout, C., Hutchinson, W. F., Willis, D. P. M. \& Shipley, P. 2004. Micro-checker: software for identifying and correcting genotyping errors in microsatellite data. Molecular Ecology Notes, 4, 535-538. DOI: 10.1111/j.14718286.2004.00684.x

Vieira, J. P., Garcia, A. M. \& Grimm, A. M. 2008. Evidences of El Niño effects on the mullet fishery of the Patos Lagoon Estuary. Brazilian Archives of Biology and Technology, 51, 433440. DOI: 10.1590/S1516-89132008000200025

Vieira, J. P. \& Scalabrin, C. 1991. Migração reprodutiva da "Tainha" (Mugil platanus, Günther, 1880) no sul do Brasil. Atlântica, 13 (1), 131-141.

Submitted: 05 May 2020 Accepted: 27 November 2020 Published on line: 18 December 2020 Associate Editor: Diego Garcia 